Témoigner Témoigner. Entre histoire et mémoire

Getuigen Revue pluridisciplinaire de la Fondation Auschwitz

Violences radicales en scène

\title{
Between word, image and movement: performative critiques of colonial ethnography
}

Tussen woord, beeld en beweging: een performatieve kritiek op

koloniale etnografie

\section{Yvette Hutchison}

\section{OpenEdition}

Journals

Electronic version

URL: https://journals.openedition.org/temoigner/3449

DOI: $10.4000 /$ temoigner.3449

ISSN: 2506-6390

Publisher:

Éditions du Centre d'études et de documentation Mémoire d'Auschwitz, Éditions Kimé

Printed version

Date of publication: 1 October 2015

Number of pages: 121-132

ISSN: 2031-4183

\section{Electronic reference}

Yvette Hutchison, "Between word, image and movement: performative critiques of

colonial ethnography", Témoigner. Entre histoire et mémoire [Online], 121 | 2015, Online since 01 October

2016, connection on 04 February 2022. URL: http://journals.openedition.org/temoigner/3449 ; DOI:

https://doi.org/10.4000/temoigner.3449 


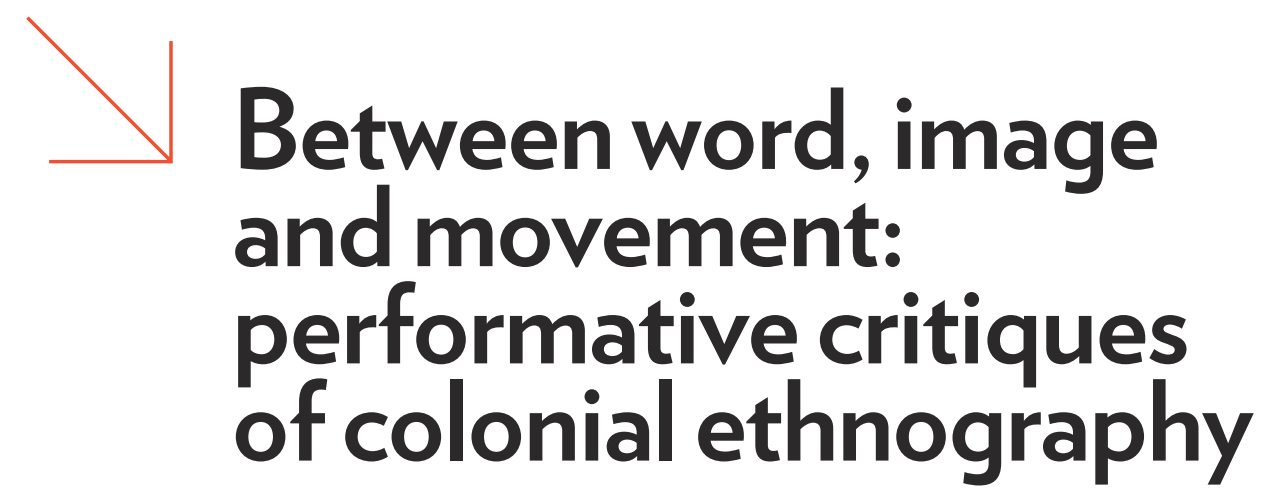

$\rightarrow$ Yvette Hutchison, University of Warwick 
performed at the National Arts Festival, South Africa, in July 2012. Historian Pascal Blanchard curated Exhibitions. L'invention du sauvage at the Quai de Branly Museum in Paris (29 November 2011 - 3 June 2012); and European Attraction Limited restaged a human zoo in Oslo from May to August 2014, to mark the $100^{\text {th }}$ anniversary of the Norwegian Jubilee Exhibition of 1914. These performances have met with varying degrees of protest, because of the traumatic nature of the material and, I would argue, the aesthetics through which they chose to explore it. ${ }^{1}$

The two following performances' critical engagement with colonial ethnography suggests how a carefully crafted aesthetic can simultaneously problematize past ethnographic issues, while situating an audience actively in the present. This facilitates what Fabian, drawing on Dell Hymes and Eric Wolf's work, calls "intersubjective time" (Fabian 1983, 24), which rejects the older anthropological approaches to "temporalize" cultures, and thereby distance them from the time of the observer, and implicates the present in the past, the observer in the installation.

\section{ACTION ZOO HUMAIN: THE TRUTH COMMISSION, GHENT, 2013}

Action Zoo Humain is an artistic collective formed around director/researcher Chokri Ben Chikha and director/actor Zouzou Ben Chikha that engages directly with Belgium's colonial past, and how it resonates in the present. Their play De Waarheidscommissie/The Truth Commission was first staged in Ghent in 2013, at the $100^{\text {th }}$ anniversary of the Ghent World fair, which is its critical focus. The website, "Ghent, 1913-2013, the century of Progress", articulates the official Belgian position on this event. It describes this exhibition as "the $28^{\text {th }}$ in a long row of exhibitions which had been organized in Europe and America since 1851", and highlights its scale and backing "by pacesetters from the private sector, by eminent industrials and representatives of the social elite in Ghent". The section entitled "Ark of Mamon" defends its place in the $19^{\text {th }}$ century scramble for Africa, suggesting that "Belgium showed the world that it was absolutely right to seize the enormous territory in Central Africa from the hands of the severely contested 'owner' king Leopold II". Under the title "Exotic amusement", it narrates how "the visitors could also enjoy themselves on the world exhibition". This "ark" also included references to exotic specimens on display in a Filipino and a Senegalese village, where visitors came to gaze at “'these savages' with their bizarre way of life”, before suggesting the salacious content had provoked strong resistance from the church on moral grounds.

In contrast, the play's titular reference to the South African Truth and Reconciliation Commission (TRC, 1996-1998) highlights the company's intention to use this play to engage critically with this colonial history and its resonances in contemporary Belgium, while placing the personal narratives of survivors and perpetrators at the

(1) See James Thompson (2009) on the compulsion and complexities of retelling unspeakable stories, and the impact of aesthetic form on affect. heart of it. It also signals this as verbatim or documentary theatre, which blurs the boundary between what is "real" and what is fictional, while provoking questions about how we access truth, and ascertain veracity. The structure itself defines the function of the form, as verbatim plays interrogate a formal version of a traumatic 


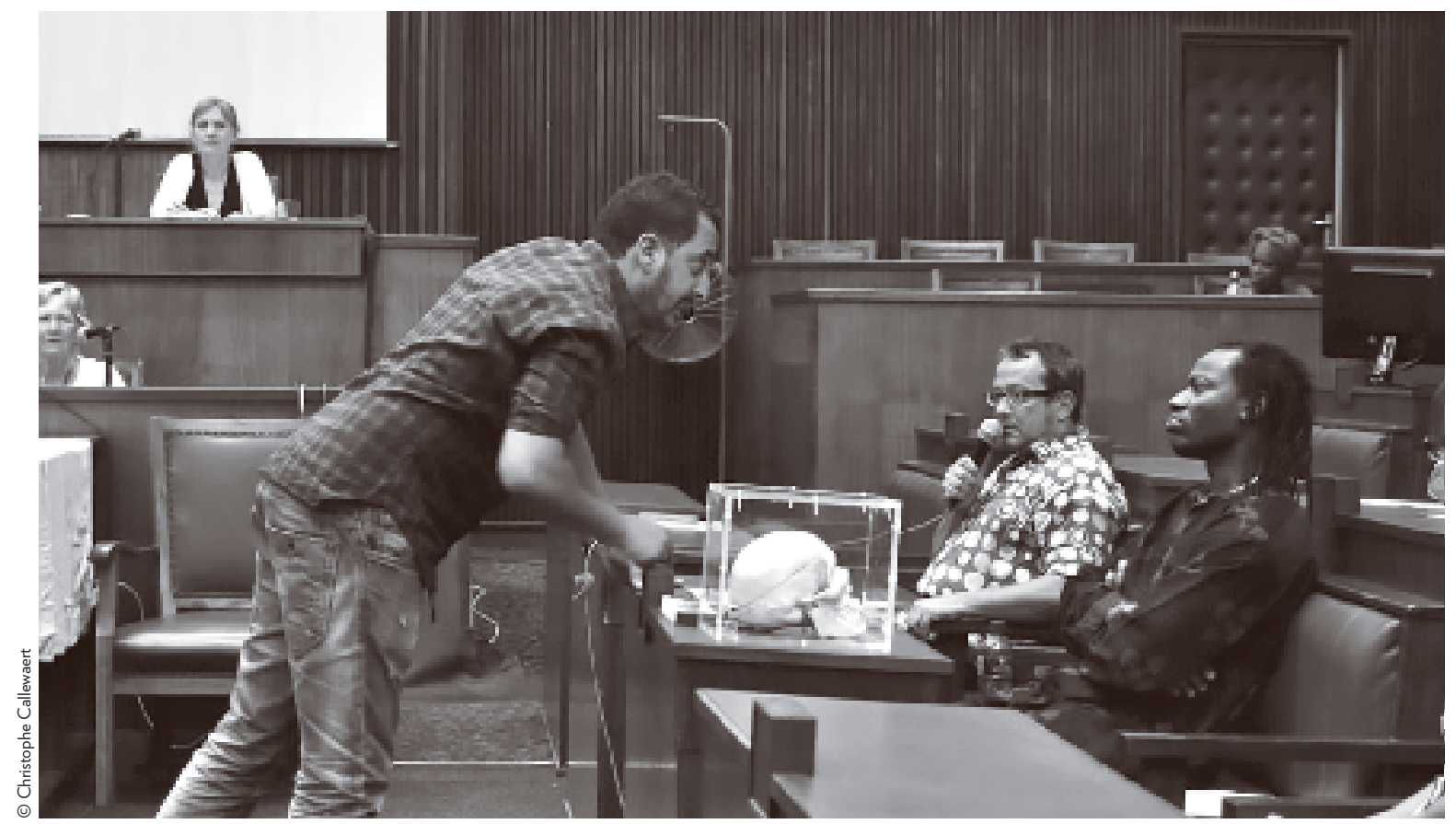

event - here the 1913 World Fair in Ghent - in an attempt to challenge the findings formally accepted by the State, while simultaneously allowing a collective exploration of the trauma for survivors, in this case descendants of the Senegalese people exhibited, and by association other formerly colonized peoples. Martin suggests that verbatim "self-consciously blends into and usurps other forms of cultural expression such as political speeches, courts of law, forms of political protest and performance in everyday life" $(2006,10)$, thereby highlighting the failure of these institutions and proposing a gravitas for the theatrical event. This reference to other cultural forms is signalled in this production by the characters represented in the play and the venues chosen for the performances.

The play's Commission is chaired by a significant public figure, Herman Balthazar, an academic and ex-governor of East-Flanders. In South Africa his co-Commissioners were Mrs Josiane Rimbaut, a news reporter, Mrs Marijke Pinoy, an actress and mother of five, Christopher Kudyahakudadirwe, an African historian and activist, and Ilse Marien, who is responsible for the social inclusion of immigrants in Belgium. Bodé Owa played a relative of the Senegalese man, Madi Diali, who died in the Ghent exhibition and whose remains, represented in South Africa by a skeleton, and in Belgium by moulded heads, he wants the Belgium government to repatriate. Dr. Verdoolaege (Ghent University) is a researcher who presents "facts" regarding the conditions and experiences of the Senegalese people in the 1913 Exhibition. Tom Lanoye, Flanders' best known and highly acclaimed playwright, plays the role of Cyriel Buysse, a Flemish naturalist and playwright who fought for the rights of the
_ Mourade Zeguendi, Tom Lanoye, Bodé Owa and (above left) Marijke Pinoye in South Africa. 
Flemish language, but whose writing also included racist passages. This mixture of identifiable people and actors representing historic characters or contemporary figures indicates various positions in the debate regarding Belgium's colonial past and how it continues to resonate in the present, as signalled by references to its programmes for integration and language policies for immigrants.

The performances took place in specific, resonant spaces: in Belgium De Waarheidcommissie was performed in April 2013 in the former Court House on the Koophandelsplein in Ghent; and in South Africa it was performed in February 2014 in the Senate building at the University of the Western Cape, which was the former "coloured" Chamber of the Tricameral Parliament of South Africa between 19841994. These spaces invoked the venues' histories and socio-political roles, both in the past and present. They also denied audiences the comfort of passively watching the proceedings, as in both contexts audiences faced one another - on the traverse in Ghent, and square formation in Cape Town - which meant that audiences actively saw one another's reactions to the proceedings, especially when they were directly addressed by those testifying.

Both the spatial arrangements and testimonial form invited audiences to "bear witness", a term that conjures a law court, where witnesses' testimonies become the basis for a verdict; community support groups where individuals publicly acknowledge faith or a taboo secret, like alcohol dependence; or where one is called upon to report on a significant event at which one has been an agent or bystander. All of these instances require individuals to actively speak out and take a position regarding an issue or event. Action Zoo Humain overtly invited audience members "to take part in the Truth Commission [... and] watch and listen to the witnesses to [sic] the dubious event of 1913, testifying in word, image and movement" (Invitation, February 2014, Cape Town).

The fact that testimony is given in "word, image and movement", transcends the privileging of spoken testimony of most Commissions, although the South African TRC did include songs and hymns. Embodied forms are important because they facilitate complex and fluid meaning making that must be completed by audience members as they interpret what they see and/or hear in relation to what they already do/not know or believe. So, for example, Owa's ritual drumming or Chantal Loial's dance as testimony is interpreted against other experiences or knowledge audience members may have of the histories being incorporated into the testimony. Thus the performances and how their meanings are arrived at are placed against fixed narratives of identities, histories and memories created during and after colonialism, and disseminated via school curricula, museums or other collective formulations of the past. This places "then" and "now" in dialogue and blurs specific temporal-spatial referents and performance modes, thus invoking Fabian's intersubjective temporality, and destabilizing the way audiences make meaning about the past. After Loial's dance the actress-Commissioner indeed raised concerns about this performance which left her feeling "disturbed, confused, like a voyeur", and she suggested that "this dance was maybe not in the right place as it was not a theatre or museum, 

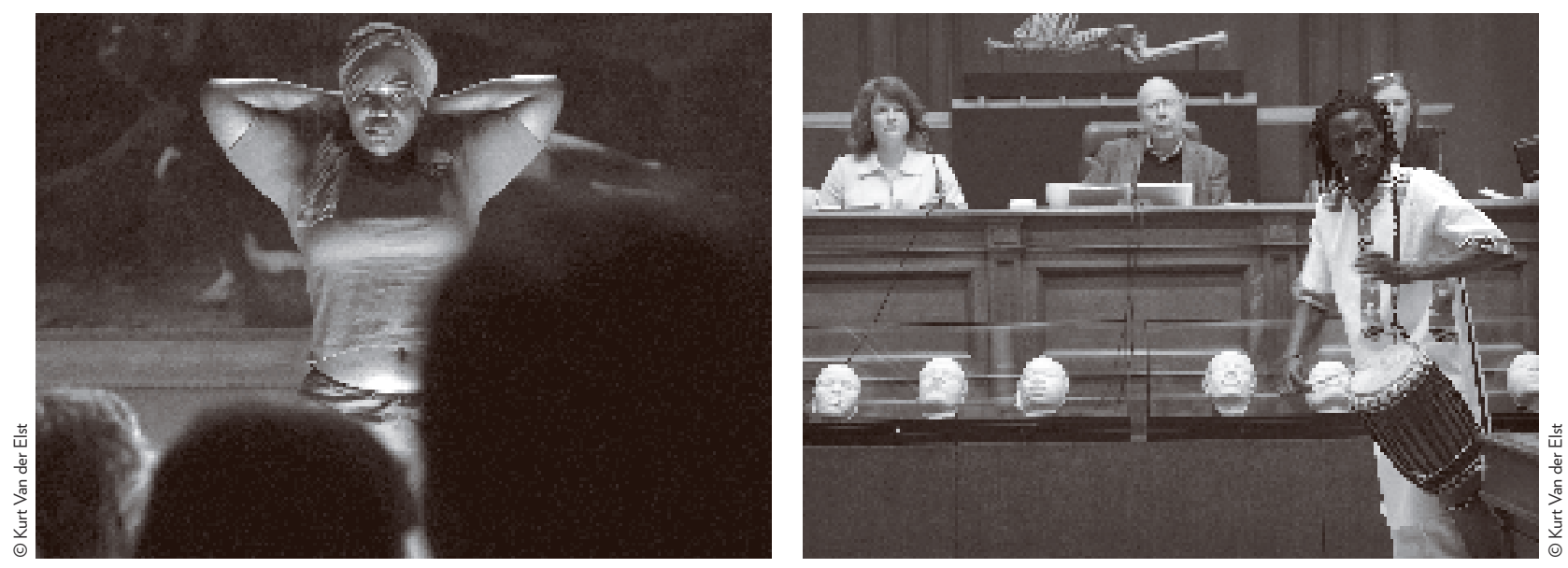

but a commission”. The whole scene demonstrates the ethical issues involved in re-representing subjugated people from the past in the present, as the past and its representations segue into the present, and issues of representation and reproduction re-emerge and converge.

Another way in which the play segues the past and present is by means of Mourade Zeguendi's participation as a contemporary Moroccan immigrant to Belgium who constantly interrupted proceedings with requests for translation of what was being said, and objections to Belgium's immigrant integration programme, which irritated the Belgian commissioners. However, the audience realizes that language is at the heart of much of Belgium's politics, as the status of French and Dutch has long been debated. This segue overlays issues of cultural hegemony experienced by previously subjugated European minority groups with contemporary issues related to immigration, thereby questioning the extent to which we are truly "post-colonial". And the xenophobic attacks on immigrants in South Africa that have continued since 2008 suggest that the colonial legacies of separating African people along linguistic and cultural lines continues to resonate in the present (see Mamdani, 2001).

However, Zeguendi also highlights broader assumptions about what is African, and the complexities involved in interpreting unfamiliar embodied performances when he objects to the Senegalese man's impassioned ritual dance between the first and second hearings. Zeguendi accuses him of dancing "like a monkey" for white people, as his ancestors did in the zoo. The irate Owa insisted that neither the audience nor Zeguendi had understood the ritual he had performed for his ancestors; and that he neither wants to perform for whites, nor does he need anyone to defend or moderate him, thereby forcing the audience to consider how their expectations regarding the performance context and their own previous knowledge of African performance and cultures had influenced their understanding of the dance and the histories with which it was engaged. 
These challenges regarding audience positionality and their processes of interpretation are important, as they demonstrate how a performance can offer more than a polemical viewpoint on complex colonial issues if the aesthetic is significantly nuanced. South African theatre director Mark Fleishmann suggests that performance can involve a kind of transformation when "a physical action or gesture begins as one thing and metamorphoses into something else passing through a range of possibilities in between" $(1997,204)$. This is most evident in the embodied performances, which remain ambiguous in this play. The physical action "opens up a plural field of possibility for the spectator. Each image is in this sense dialogical: a play of open-ended possibilities interacting between two fixed poles which exist in some form of dialogue with each other" (ibid, 205). For example, Loial's dance and Owa's ritual dance and drumming appear to be expressions of specific cultural memories and identities; but within the frame of this debate and the play as a whole play, they encourage audiences to reflect on what they know about these cultures and assume about the identities. The embodied performances thus provoke audience members to consider how and from where they have received the knowledge that informs their assumptions regarding these repertoires, while facilitating an awareness of alternative possibilities and perspectives on these cultures. This challenges our assumptions that colonialism is just past history, and makes us aware of how colonial hegemonies of knowledge and representation continue to resonate in the present.

However, the documentary style is complex insofar as it proposes itself as a live, authentic event, despite its being clearly scripted (with translations projected onto the screen in South Africa). Assumptions are important - we presume that a theatrical event occurs in the safe space of fiction, while a public hearing is presumed to have consequences beyond the performance. The fact that the play ended with the commission proposing to hand specific recommendations regarding the processing of African artists' visas, reparations of wages for Senegalese descendants of those in the Human Zoo of 1913, and the inclusion of this aspect of Flemish history in the school curricula to Belgian government officials, raises questions regarding the potential efficacy of theatre beyond facilitating awareness to suggest that it could impact on cultural policy-making regarding the colonial past. This seemed utopian to me, but may be an extension of documentary theatre's attempt to "construct the past in service of a future the authors would like to create" (Martin 2006, 10).

Nevertheless, this play's commitment to actively engage audiences beyond their consideration of the past was evidenced at the end, when Chokri and Zouzou Ben Chikha wished the performers a good evening in Cape Town, and then required the visiting performers to hand over their passports to prevent the possibility of their illegal disappearance. The audience were asked to speak for or against this control of foreign visitors, and in some performances in Ghent and Cape Town the debate became quite heated. This move into invisible theatre shifted the show from the realm of ideas to action, as people had to analyze their attitudes to contemporary "others" against the backdrop of the show's engagement with the Ghent human zoo, and actively take a stand on this current issue. It engaged spectators as active 
witnesses whose speech acts for or against the African performers had real implications in the present, and potentially in the future insofar as this could be seen as a rehearsal for civil action, potentially leading to new cultural policy on immigrants' mobility rights.

It is clear that the ways in which this performance critically reflected on the history of Ghent's 1913 human zoo, and segued past and present time and space, facilitated a dialogic revisioning of contemporary audiences' values and senses of accepted history. It highlighted gaps in knowledge and the different experiences of contemporary lived experiences in Belgium or South Africa. It also demonstrated the difference context makes for establishing values, which further complicates how we re-evaluate the past. The performance form was itself important, creating a space out of time, which allowed audience members to engage with the past and/ in the present, without accusing or alienating them.

How though, does one engage an audience with potentially offensive ethnographic material?

\section{INSTALLATION - BETWEEN WORDS AND IMAGES, CAPE TOWN, 10 OCTOBER 2013 - 31 JANUARY 2014}

Ernestine White, with oral poet Toni Stuart, created Between Words and Images specifically for IZIKO's Rust en Vreugd Museum. The museum currently houses the William Fehr (1892-1968) Collection, consisting of European art works dating from the late $17^{\text {th }}$ to the early $19^{\text {th }}$ centuries, including ethnographic drawings of "native" peoples of South Africa. It sought to engage visitors with issues surrounding ethnographic writing and drawings from the $18^{\text {th }}$ century onward, particularly the work of French explorer François Le Vaillant. ${ }^{2}$

In 1963 H.J. Klopper, Speaker of the House of Parliament in South Africa, authorized the Librarian of Parliament to purchase "a collection of 165 water-colour drawings illustrating the travels in South Africa of François Le Vaillant" when these were advertised for sale at Sotherby's auction rooms in London. He also recommended that the Library Committee of Parliament "should grant permission to the South African National gallery to exhibit the pictures in order that as many of the general public as possible may have the opportunity of viewing them" (South African National Gallery, 1965, Foreword). Today Le Vaillant's aquarelles and travelogues in two volumes, translated and reproduced in English and German from the original French manuscripts, are kept in a closed archive in the South African Parliament because they contain material considered racially and gender "sensitive". It is from this material that artist Ernestine White drew for her installation, particularly the account of Le Vaillant's encounter with an "unknown Hottentot woman".

The installation sought to consider the role Le Vaillant's ethnographic drawings and writings played in the European colonial narrative. Ian Glenn, curator of the exhibition “The King's Map, Francois le Vaillant in Southern Africa: 1781-1784”, argued that "Le Vaillant played a major role in establishing how Europe saw the
(2) Le Vaillant was born of an old and distinguished family of a French jurist of Verdun origin. However, when his father, an official of high rank in the Court of Metz, eloped with a girl, they fled to the Dutch colony of Suriname in South America where he became the French consul, and a wealthy merchant. François spend his childhood in this village and accompanied his father on journeys into the interior, but when his family returned to Europe, he completed his education in Metz and spent years travelling in western Europe. He became a crack marksman and also made a study of all the large "cabinets" of animals and birds. 
Cape", and could be considered "a founding figure of South African culture" (Iziko, 2013). However, this analysis is silent regarding the legacy of Le Vaillant's depictions of the indigenous peoples of South Africa, particularly the Hottentot women as highly sexualized and aberrant.

What is important about the installation is the ways in which White and Stuart raise these issues without replicating the images and voyeurism of the original work. Firstly, White demonstrates a keen awareness of the significance of Rust en Vreugd: originally the house of Willem Cornelis Boers, a high-ranking official of the VOC (Dutch East India Company), it was built in 1778, and was the base from which Le Vaillant catalogued his collections. Although it now houses art dating from a significant period of South Africa's colonial history, it does not overtly engage with this context or history as the IZIKO Slave Lodge does.

White's aesthetic choices demonstrate her acute awareness of her potential audience: predominantly European tourists who come to see colonial furniture and pictorial Africana, and thus would "accidently" engage with her installation. ${ }^{3}$ The artist engaged her audience in just one room, toward the front of the house, which displays ethnographic prints/lithographs of two English naturalist painters, George French Angas (1822-1886) and Samuel Daniell (1775-1811). In the corner of the room White placed a floor to ceiling plaque with extracts from the travels of Francois Le Vaillant that relate his experience of seeking out a Hottentot woman to confirm and record the "peculiar conformation" of her genitalia (1790, 349-351). Towards the centre of the room White placed two chairs: one roped off facing another temptingly available to sit on. When a visitor sits down, perhaps to contemplate the paintings, an eight and a half minute poem, "the woman" by Toni Stuart, is triggered, which offers her imagined response to the Hottentot woman's experience with Le Vaillant. However, if at any time the visitor gets up, the soundscape stops.

The whole aesthetic is subtle: first, the visitor contemplates the images and reads extracts from Le Vaillant's travelogue, as is usual in a museum or gallery space. However, the aural soundscape shifts the installation into performance. The mise en scene simultaneously places the empty chair, signifying the absent subject, in this case, the Hottentot woman, alongside other ethnographic images and the aural narrative. Thus the visitor inhabits an imaginative space between Le Vaillant's words and the ethnographic images that are part of his legacy, without White replicating his images.

The poem engages the visitor with the consequences of the colonial gaze, which has rendered its subject nameless. It begins

(3) A secondary audience were the ancestors of the indigenous people and slaves of Cape Town, who were invited to the opening of the installation, but whose responses I will not analyze here. i want to tell you my name

whose sounds you stripped and shattered

whose letters you scraped from my skin

Its use of first person narration and direct address directly implicates the hearer, while blurring the time-frames, and making the past immediate in the present. 

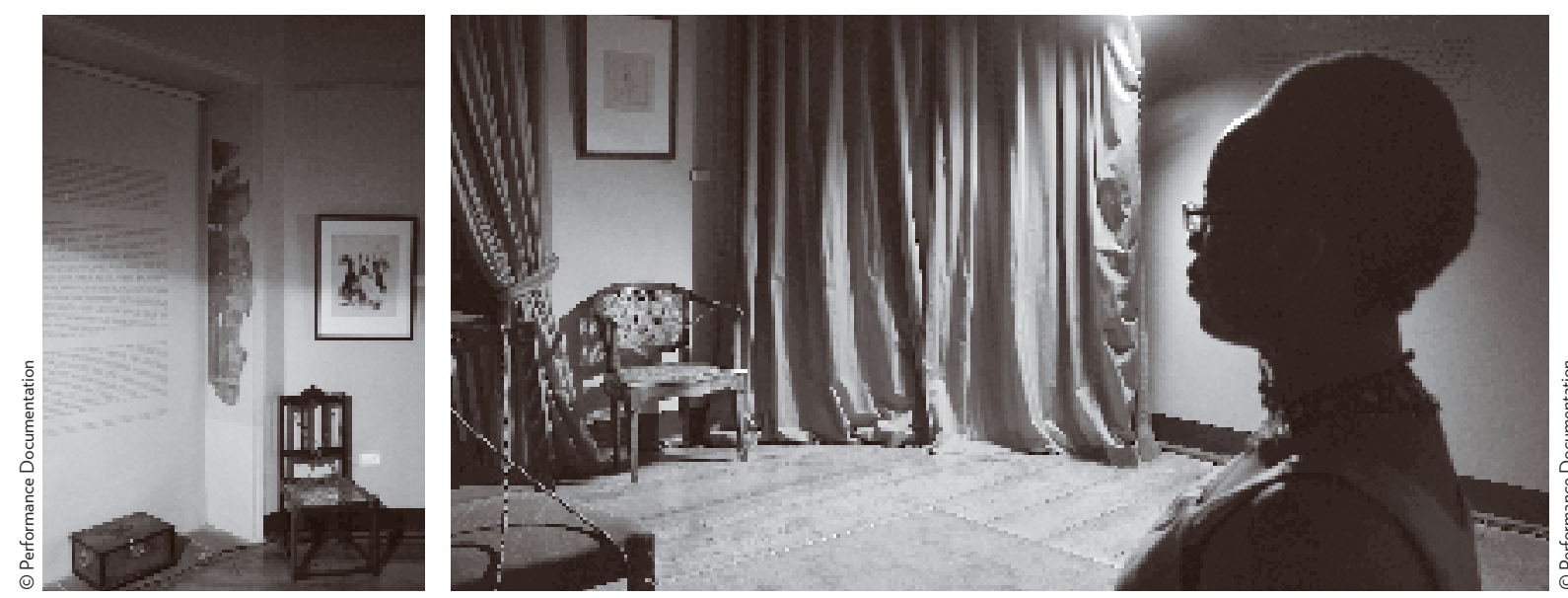

The woman outlines her intention to use

rhythm and chorus

until my voice seeps under your skin like a shadow

and its echoes trace a path up your neck

to burn the unseeing from your eyes
_ Ernestine White sitting facing the empty chair, Between Words and Images, 2013.

This suggests the power of art to "get under our skins", and touch us viscerally, in order to engage us personally in the disavowed aspects of the colonial endeavour. The "unseeing" includes recognizing that European men brought gifts "not to honour me, but to beg for my humiliation", and implicated indigenous men in supporting their requests for access to their women:

my brothers' voices join with yours

speaking words that betray their souls and mine

your voices rise, knives against my flesh

The second stanza invites the visitor to imagine the woman's response to this experience, while implicating the viewer who is gazing at ethnographic paintings as the woman says:

your science strips me of my sacredness

your gaze desecrates my flesh

and the shattering of my name is complete

The third stanza poses sharp questions regarding the destination of colonial ethnographic collections like these, asking 
(4) Many scholars argue that Baartman was "a foundational figure in the rise of racial science and cultural perceptions of the black female body", see Scully \& Crais 2008.

(5) This is particularly significant in South Africa where The PostRape Care Centre reported in 2008 that "a female born in South Africa has a greater chance of being raped in her lifetime than learning how to read". See http:// ubuntunow.org/2008/09/childrape-in-south-africa/ (accessed 1 July 2012), http://rapecrisis.org. za/rape-in-south-africa/\#_ftn1 for 2011-2012 figures.

(6) Conquergood argues that this is because "the root metaphor of the text underpins the supremacy of Western knowledge systems by erasing the vast realm of human knowledge and meaningful action that is unlettered" $(2002,147)$. The strong and diverse feelings expressed both in protest on 23 September 2014 and in the media over the staging of Brett Bailey's Exhibit $B$ in London exemplifies these issues, and the debates that can arise from them. For an analysis of this production see Chikha \& Arnaut 2013. what have you done with my pictures?

whose eyes pierce, sear and defile my flesh

a second, a third, a hundredth time [...]

and what of the other women's bodies

- pulled apart in death, to unpack our sacredness -

whose drawings of flesh

you printed in the name of science

black women's bodies pulled apart

to prove your prejudice. to justify your hate

Here the visitor is challenged to consider the implications of their engaging with colonial ethnography as a passive cultural experience, which in reality played a significant role in justifying the subjugation and oppression of colonial subjects. The stanza's refrain clearly articulates the artists' positions on contemporary ownership of ethnographic drawings or body parts, like those of Sarah Baartman, ${ }^{4}$ as the voice calls for us to "cover me please".

The poet's voice, breathe and pauses are important. They break silences on disavowed experiences and histories, and thus challenge the tyrannical hold of the original story of the coloniser, and the dominant view of the artefacts. It highlights such ethnographic images as being both problematic representations of subjugated peoples, and part of the state apparatus that normatised attitudes to race and gender in ways that continue to inform the lived experiences of these people, especially women. ${ }^{5}$

The aesthetics of this installation are innovative and point the way towards how artists may engage with colonial ethnography without replicating the imagery. The soundscape raises complex questions regarding the legacies of colonial ethnography both literally and conceptually, without accusing or alienating the spectator. This is because the hearer is drawn into the speaker's imagined recollection of this violation of privacy and personhood. It is in their own imagination that the visitors perceive the woman's sense of humiliation and erasure, and its implications. This aesthetic also prevents the artist from having to represent the absent subject.

\section{CONCLUSION}

The fact that if a viewer physically got up, silence resumed in White and Stuart's installation, and the voting could affect the mobility of performers in Truth Commission, suggests how a performance lens can "open the space between analysis and action, and [...] pull the pin on the binary opposition between theory and practice" (Conquergood 2002, 145). ${ }^{6}$ Both performances suggested the potential for future civic action by spectators.

Both performances challenged the ways in which nations define themselves through coherent historical narratives and visual representations of a shared past that is not "past". Fanon has argued that the native is always in the process of one form 
of liberation or another, and that the drama unfolds in three stages: assimilation, rejection, and revolution (Fanon 1963, 166-199). In the "fighting" or revolutionary phase, the intellectuals and artists return to engage with their people in the now, apart from notions of "tradition", or is overwritten by miming the coloniser. Fanon writes:

it is not enough to try to get back to the people in that past out of which they have already emerged; rather we must join them in that fluctuating movement which they are now just giving shape to, and which, as soon as it has started, will be the signal for everything to be called into question. Let there be no mistake about it; it is to this zone of occult instability where the people dwell that we must come; and it is there that our souls are crystallized and that our perceptions and our lives are transfused with light (Fanon 1963, 182-183).

Fanon is here arguing for engaging with the past in such a manner that it opens the way to a future that provides hope for change. However, change is dependent on action. He argues for the ideologies of a national culture to be more than conceptual, but rather the means by which national culture can deconstruct colonialism and formulate itself in the present (Ibid, 188-191). It is thus crucial that artists highlight this "zone of instability" when re-engaging with colonial histories and ethnographies. Bhabha argues that

[it] is from this instability of cultural signification that the national culture comes to be articulated as a dialectic of various temporalities - modern, colonial, postcolonial, "native" - that cannot be a knowledge that is stabilized in its enunciation. (Bhabha 1994, 218-219)

Performance can highlight these various temporalities simultaneously in the present. Their chosen aesthetic can resist merely re-presenting colonial histories, and shift the focus to highlighting the hegemonic processes involved in such representations. By creating an aesthetic that involves spectators, performances can help contemporary spectators to actively position themselves in relation to the material, analyzing what hegemonic knowledges have informed their sense of the colonial past, and how this knowledge has impacted on the formulations of their present value systems and potential future policy.

Both pieces demonstrate the multiplicity of memories in relation to the colonial event, and the importance of acknowledging specific historic and geographical contexts when engaging with them. The mobilization of a repertoire of embodied performance forms (dance, drumming, song, poetry) in relation to archives (documents, art, artefacts) is one way to destabilize a fixed narrative of the past. In highlighting different kinds of subjectivities regarding the past and present, the performances facilitate intersubjective dialogue between them, implicate the spectator and suggest their potential agency in engaging with the issues raised. The intersubjectivity I refer to here is not within a person as in Lacan and Foucault, but with the mechanisms that work between people, as the location for the negotiation of representations, 
narratives and meanings that are affected by various hegemonies, which in turn affect our subjectivity (Holloway 1989; Passerine 2007). So we revisit the Ghent exhibition of 1913 , or ethnographic drawings of the $18^{\text {th }}$ and $19^{\text {th }}$ centuries, not only to explore what they meant "then", but to ask how "then" impacts on "now", and how the "now" will impact on tomorrow. The theatrical frame allows us to imagine this possibility and, as Jill Dolan argues, collectively "share experiences of meaning making and imagination that can describe or capture fleeting intimations of a better world" $(2005,2)$.

\section{WORKS CITED}

- Bhabha, Homi K., The Location of Culture, London \& New York: Routledge, 1994.

- Chikha, Chokri Ben \& Karel Arnaut, 'Staging/caging “otherness” in the postcolony: spectres of the human zoo', Critical Arts: South-North Cultural and Media Studies, 27(6), 2013, 661-683.

- Conquergood, Dwight, 'Performance Studies: Interventions and Radical Research', TDR 46(2), 2002, 145-156.

- Dolan, Jill, Utopia in Performance: Finding Hope at the Theater, Ann Arbor: University of Michigan Press, 2005

- Fabian, Johannes, Time and the Other: How anthropology makes its object, New York: Columbia University Press, 1983.

- Fanon, Frantz, The Wretched of the earth [1961], translated by C. Farrington, preface by Jean-Paul Sartre, New York: Grove Press, 1963.

- Fleishman, Mark, 'Physical Images in the South African Theatre', South African Theatre Journal, 11(1\&2), 1997, 199-214.

- Holloway, W., Subjectivity and Method in Psychology: Gender, Meaning and Science. London: Sagen 1989.

- Le Vaillant, François, Travels into interior parts of Africa by way of the Cape of Good Hope in the years 1780, 81, 82, 83, 84, 85, vol 2, London: printed for G.G. and J. Robinson, 1790.

- Mamdani, Mahmood, 'Beyond Settler and Native as Political Identities: Overcoming the Political Legacy of Colonialism', Comparative Studies in Society and History, 43(4), 2001, 651-664.

- Martin, Carol, 'Bodies of Evidence', TDR 50(3), 2006, 8-15.

- Passerini, Luisa, Memory and Utopia - The Primacy of Intersubjectivity, London: Equinox, 2007.

- Sauvage, Alexandra, 'To be or not to be colonial: Museums facing their exhibitions', Culturales 6(12), 2010, 97-116.

- Scully, Pamela \& Clifton Crais, 'Race and Erasure: Sara Baartman and Hendrik Cesars in Cape Town and London', Journal of British Studies 47(2) 2008, 301-323.

- Taylor, Diana, The Archive and the Repertoire: Performing Cultural Memory in the Americas, Durham \& London: Duke University Press, 2007.

- Thompson, James, Performance Affects (2009), Basingstoke \& New York: Palgrave Macmillan, 2011.

Websites

- Action Zoo Humain, http://www.actionzoohumain.be/en, accessed 2 January 2015.

- 'Ghent, 1913-2013', the century of Progress, http://1913-2013.gent.be/en/ghent-wants-have-largest-world-fair, accessed 22 July 2014.

- Edinburgh Festival 2014, http://www.eif.co.uk/2014/exhibitb, accessed 15 August 2014.

- IZIKO, lan Glen, AA map fit for a king', 19 March 2013, http://www.mediaclubsouthafrica.com/culture/3288-amap-fit-for-a-king181\#ixzz38HpDKwcU, accessed 2 January 2015. See also http://www.iziko.org.za/calendar/ event/francois-le-vaillant 